\title{
Efektifitas Aplikasi Handrub Terhadap Perubahan Pola Mikroorganisme Pada Tangan Petugas di Rumah Sakit Penyakit Infeksi Prof. Dr. Sulianti Saroso
}

\section{The Effectiveness of The Application of Handrub on Changes in Microorganism Pattern on Medical Staff Hands at Infectious Disease Hospital of Prof. Dr. Sulianti Saroso}

\author{
Nadiatul Maunah \\ RSPI Prof. Dr. Sulianti Saroso, Kementerian Kesehatan Republik Indonesia
}

\begin{abstract}
Abstrak : Healthcare-Associated Infection (HAls) merupakan masalah serius tidak hanya terbatas di rumah sakit saja tetapi juga disemua fasilitas pelayanan kesehatan. Salah satu pencegahan HAls adalah dengan menjaga kebersihan tangan. Tujuan penelitian ini adalah mengetahui efektifitas handrub terhadap perubahan jumlah mikroorganisme pada tangan petugas Rumah Sakit Penyakit linfeksi Prof. Dr. Sulianti Saroso.Penelitin ini merupakan penelitian pre experimental dengan pre and post test without control design. Efektifitas perlakuan dinilai dengan cara membandingkan jumlah mikroorganisme dan pola mikroorganisme sebelum handrub, sesudah handrub 1 dan sesudah handrub 5. Sampel dalam penelitian ini adalah 69 perawat Rumah Sakit Penyakit Infeksi Prof. Dr. Sulianti Saroso yang bekerja di ruang rawat TB (Dahlia 1), ruang rawat HIV-AIDS (Dahlia 2), Ruang Intensif (ICU), dan ruang anak (Nusa Indah 1), kebidanan ( Nusa Indah 3) yang diambil dengan teknik purposive sampling. Mikroorganisme yang ditemukan ditangan petugas kesehatan Rumah Sakit Penyakit linfeksi Prof. Dr. Sulianti Saroso sebelum handrub adalah mikroorganisme transien dan residen yaitu : jamur, Staphylococcus epidermidis, Acinetobacter anitratus, Enterobacter cloacae dan Citrobacter sedangkan mikroorganisme setelah handrub 1 dan ke 5 adalah jamur dan Staphylococcus epidermidis. Jumlah koloni sebelum handrub maksimal 150 koloni, sedangkan jumlah koloni setelah handrub 1 dan ke 5 maksimal 87 dan 75. Hasil uji Friedman menunjukkan adanya perbedaan jumlah koloni dari ketiga perlakukan (sebelum, sesudah tindakan handrub 1 dan handrub 5 diperoleh $(P$ value=0.000). Tindakan handrub merupakan perlakuan yang efektif dalam menekan jumlah koloni mikroorganisme di tangan.
\end{abstract}

Kata Kunci : Healthcare-Associated Infection (HAls), Handrub

\begin{abstract}
Healthcare-associated infection (HAls) is a serious problem should not be limited in the hospital but also all these health service facilities. One of the prevention of HAls is by maintaining healthy hand. The purpose of this research is to know the effectiveness of hand rub on changes in the number of microorganisms on medical staff hands at infectious disease hospital of Prof.Dr.Sulianti Saroso. The research is pre-research experiment with pre and post-test without control design. The effectiveness of treatment is considered by means of compare the number of microorganisms and the pattern microorganisms beforehandrub, after handrub 1 and after handrub 5.Samples in this research were 69 nurses hospital of infection diseases Prof.Dr.Sulianti Saroso worked in tuberculosis (Dahlia 1) ward, HIV-AIDS room (Dahlia 2) ward, intensive (ICU) Unit, and pediatric (Nusa Indah 1) ward, obstetrics (Nusa Indah 3) ward, the research was taken with purposive techniques of sampling. These microorganisms which found on the health workers at hospital of infectious disease Prof.Dr .Sulianti Saroso before handrub is transient and resident microorganisms i.e. fungi, Staphylococcus epidermidis, Acinetobacter anitratus, Enterobacter cloacae and Citrobacter mikroorganism mean while after hand rub 1 and 5 are fungi and staphylococcus epidermis. The number of a colony before handrub a maximum of 150 colony,otherwise the number of the colony after handrub 1 and to 5 a maximum of 87 and 75. The result of friedmantest stated that there are differences in the number of colonies of third implementation (before, after the implementation of handrub 1 and 5 handrub obtained (pvalue=0.000). The implementation of handrub is effective treatment in reducing the number a colony microorganisms in the hands.
\end{abstract}

Keywords : Healthcare-Associated Infection (HAls), Handrub

Korespondensi : Nadiatul Maunah

RSPI Sulianti Saroso, JI. Baru Sunter Permai

Raya Jakarta Utara 14340

Phone : 021-6506559Fax : 021-6401411

Email : rose women12@yahoo.com

\section{PENDAHULUAN}

Healthcare-Associated Infection (HAls) merupakan masalah serius tidak hanya terbatas di rumah sakit saja tetapi juga disemua fasilitas pelayanan kesehatan. Setiap tahun, ratusan hingga jutaan pasien di seluruh dunia terkena dampaknya. Healthcare-Associated 
Infection (HAls) merupakan kejadian merugikan yang paling sering terjadi pada saat proses pelayanan kesehatan meskipun pada prinsipnya hal ini dapat dicegah. Healthcare-Associated Infection (HAls) dapat mengakibatkan perawatan yang lama dirumah sakit, peningkatan resistensi mikroorganisme terhadap antimikroba dan peningkatan biaya perawatan ${ }^{1}$.

Kulit manusia didiami oleh banyak bakteri yang berkoloni. Bakteri ini dapat menyebar di lingkungan sekitar pasien seperti tempat tidur, selimut, perabot, bahkan tiang infus sekalipun. Penelitian Casewell \& Philip menunjukkan bahwa tangan perawat dapat mengkontaminasi pasien dari Klebsiella spp sebanyak 1001000 CFU selama tindakan seperti mengangkat pasien, mengukur denyut nadi, tekanan darah suhu, atau menyentuh tangan pasien, bahu atau pangkal paha ${ }^{2}$. Penelitian Ehrenkranz pada 88 tangan perawat 10-600 CFU / ml dalam sarung tangan ditemukan P.mirabilis ${ }^{3}$. Pittet dan rekan menemukan jumlah bakteri dari ujung jari berkisar 0300 CFU. Dari tangan petugas kesehatan yang terkontaminasi pada saat sebelum dan sesudah kontak langsung dengan pasien, luka perawatan, perawatan kateter intravaskular, perawatan saluran pernapasan atau menangani sekret pasien ${ }^{4}$.

Salah satu pencegahan HAls adalah dengan menjaga kebersihan tangan. Penelitian yang dilakukan oleh Girou et.al membuktikan bahwa cuci tangan dapat menurunkan jumlah mikroorganisme di tangan hingga $58 \%{ }^{5}$. Secara individu cuci tangan dapat meningkatkan hieginitas yang dapat berpengaruh terhadap kesehatan.World Health Organization (WHO) menyebutkan lima momen penting perlunya hand hygiene yaitu sebelum kontak dengan pasien, sebelum melakukan prosedur aseptik, setelah kontak dengan pasien, setelah menangani cairan tubuh dan setelah kontak dengan lingkungan sekitar pasien ${ }^{1}$.

Kegagalan melakukan kebersihan tangan yang baik dan benar dianggap sebagai penyebab utama infeksi nosokomial (HAls) dan penyebaran mikroorganisme multi resisten di fasilitas pelayanan kesehatan dan telah diakui sebagai kontributor yang penting terhadap timbulnya wabah ${ }^{4,6}$.

Kurangnya kepatuhan petugas dalam pelaksanaan kebersihan tangan adalah masalah yang dihadapi oleh rumah sakit di seluruh dunia. Kurangnya fasilitas seperti wastafel dan akses terhadap air bersih, sabun serta tisu pada titik pelayanan kesehatan merupakan kendala yang mempengaruhi kepatuhan mencuci tangan. Salah satu solusi terhadap hal ini yaitu dengan adanya alcohol-based handrubs. Mencuci tangan dengan alcohol-based handrubs tidak membutuhkan air bersih, sabun serta tisu dan dapat digunakan langsung di tempat bekerja. ${ }^{1,5}$

World Health Organization (WHO) merekomendasikan dua jenis formulasi handrub sebagai cairan pencuci tangan alternatif jika cairan pencuci tangan komersial sulit didapatkan ataupun terlalu mahal. Formulasi pertama memiliki komposisi yang terdiri dari ethanol, glycerol dan hydrogen peroxide. Sedangkan formulasi kedua terdiri dari isopropyl alkohol, glycerol,dan hydrogen peroxide. Formula ini memiliki spektrum luas aktivitas antimikroba dengan risiko minimal terhadap resistensi. Efektivitas antimikroba cairan pencuci tangan formula WHO telah lolos uji European Standards (EN). ${ }^{1}$

Penggunaan handrub berbasis alkohol tidak menimbulkan risiko dengan menghilangkan mikroorganisme yang secara alami ada di kulit. Tubuh dengan cepat mengeluarkan flora resident dari folikel rambut namun, alkohol juga mungkin memiliki efek negatif pada fungsi kulit ${ }^{7}$.

Penelitian ini bertujuan untuk mengetahui efektifitas handrub terhadap perubahan jumlah dan pola mikroorganisme pada tangan petugas kesehatan RSPI Prof. Dr. Sulianti Saroso. Hasil penelitian inidapat memberikan konfirmasi dan penegasan terhadap teori hand hygiene yang dijadikan dasar penelitian dan pembuktian manfaat bila dilakukan intervensi, sehingga menjadi masukan yang besifat membangun bagi RSPI Prof. Dr. Sulianti Saroso dalam membuat rencana intervensi dan juga 
sebagai bahan advokasi dalam peningkatan mutu pelayanan rumah sakit khususnya dalam pencegahan dan pengendalian infeksi.

\section{METODOLOGI}

Penelitin ini merupakan penelitianpre experimental dengan pre and post test without control desaign.Subyek penelitian dalam penelitian ini adalah 69 perawat Rumah Sakit Penyakit linfeksi Prof. Dr. Sulianti Saroso yang bekerja di ruang rawat TB (Dahlia 1), ruang rawat HIVAIDS (Dahlia 2), Ruang Intensif (ICU), dan ruang anak (Nusa Indah 1), kebidanan (Nusa Indah 3) yang diambil dengan teknik purposive sampling. Observasi pada subyek penelitian tersebut dilakukan sebanyak tiga kali, yaitu; sebelum handrub, sesudah handrub pertama dan sesudah handrub kelima pada satu kelompok tanpa pembanding. Efektifitas perlakuan dinilai dengan cara membandingkan jumlah mikroorganisme sebelum handrub, sesudah handrub pertama dan sesudah handrub kelima. Handrub dilakukan sesuai dengan rekomendasi prosedur cuci tangan medis WHO.

Teknik pengumpulan data yang digunakan dalam penelitian ini adalah dengan cara: (1) subyek penelitian menempelkan telapak tangan pada cawan petri yang berisi media agar pertama yang disediakan sebelum melakukan tindakan kepada pasien yang tidak memerlukan sarung tangan (yaitu mengukur tanda tanda vital, membersihkan lingkungan sekitar pasien), (2) subyek penelitian kemudian melakukan handrub pertama lalu menempelkan telapak tangan pada media agar ke-2 (handrub 1), (3) subyek penelitian selanjutnya melakukan handhygiene menggunakan handrub berbasis alkohol sampai handrub kelima lalu menempelkan telapak tangan pada media agar ke 3 (Handrub 5).

Cawan petri yang telah ditempelkan telapak tangan tersebut selanjutnya dikirim ke Laboratorium Mikrobiologi RSPI Prof. Dr.Sulianti Saroso untuk dilakukan pemeriksaan sesuai SOP Pemeriksaan Mikrobiologi untuk mengetahui mikroorganisme dan jumlah koloni yang tumbuh.

Analisa dilakukan terhadap perubahan jumlah koloni mikroorganisme yang tumbuh dengan menggunakan analisa univariat dan bivariat. Analisa bivariat menggunakan uji Friedman karena data berdistribusi tidak normal. teknik ini digunakan untuk menguji signifikansi hipotesis komparatif tiga sampel yang berkorelasi, dengan menggunakan sampel dependen.

\section{HASIL}

\section{Jenis Mikroorganisme dan Jumlah Koloni}

Mikroorganisme yang tumbuh pada ketiga perlakuan handrub sebagian besar adalah jamur, yaitu sebesar $70.4 \%, 70,2 \%$ dan $83,3 \%$. (Tabel 1)

Tabel 1. Jenis mikroorganisme yang tumbuh pada tangan petugas kesehatan RSPI-SS

\begin{tabular}{|l|l|l|}
\hline Mikroorganisme & Jumlah & $\begin{array}{l}\text { Prosentase } \\
(\%)\end{array}$ \\
\hline Sebelum Handrub & 57 & 70,4 \\
\hline Jamur & 20 & 24,7 \\
\hline $\begin{array}{l}\text { Straphylococus } \\
\text { epidermis }\end{array}$ & 2 & 2,5 \\
\hline $\begin{array}{l}\text { Acinetobacter } \\
\text { anitratus }\end{array}$ & 1 & 1,2 \\
\hline $\begin{array}{l}\text { Enterobacter } \\
\text { cloacae }\end{array}$ & 1 & 1,2 \\
\hline Citrobacter & 81 & 100 \\
\hline Jumlah & 19 & 79,2 \\
\hline Setelah Handrub 1 & 5 & 20,8 \\
\hline Jamur & 24 & 100 \\
\hline $\begin{array}{l}\text { Straphylococus } \\
\text { epidermis }\end{array}$ & 10 & 83,3 \\
\hline Jumlah & 2 & 16,7 \\
\hline Setelah Handrub 5 & 12 & 100 \\
\hline Jamur & 12 & \\
\hline $\begin{array}{l}\text { Straphylococus } \\
\text { epidermis }\end{array}$ & Jumlah & \\
\hline Sumber : Data Primer 2013 &
\end{tabular}

Rerata jumlah koloni terbanyak adalah sebelum tindakan handrub, dan rerata jumlah koloni paling kecil adalah setelah handrub kelima. (Tabel 2.) 
Tabel 2. Rerata jumlah koloni mikroorganisme yang tumbuh pada tangan petugas kesehatan RSPI-SS

\begin{tabular}{|c|c|c|}
\hline Perlakuan & $\begin{array}{c}\text { Rerata } \\
\text { Jumlah } \\
\text { koloni }\end{array}$ & $\begin{array}{c}\text { Standar } \\
\text { Deviasi }\end{array}$ \\
\hline Sebelum Handrub & 38.05 & 34.29 \\
\hline Sesudah Handrub 1 & 6.20 & 16.89 \\
\hline Sesudah Handrub 5 & 3.15 & 12.41 \\
\hline
\end{tabular}

Sumber : Data Primer 2013

\section{Analisis komparatif}

Analisis komparatif antara jumlah koloni mikroorganisme dilakukan dengan uji komparatif tiga kelompok berpasangan dengan terlebih dahulu dilakukan pengujiaan normalitas data secara analitik menggunakan uji Kolmogrov Smirnov. Dari uji tersebut didapatkan kesimpulan pada ketiga perlakuan didapatkan data yang berdistribusi tidak normal. Karena data berdistribusi tidak normal maka pengujian secara bivariat selanjutnya menggunakan uji Friedman.

Hasil uji Friedman menunjukkan adanya perbedaan jumlah koloni dari ketiga perlakukan (sebelum, sesudah tindakan handrub 1 dan handrub 5) $\mathrm{P}=0.000<(0,05)$ (Tabel 3). Efektifitas dari 3 perlakuan dilihat dari rata-rata jumlah koloni yang tumbuh, yang paling sedikit yaitu sesudah tindakan handrub kelima.
Sehingga dapat disimpulkan bahwa tindakan handrub merupakan perlakukan yang efektif dalam menekan jumlah koloni mikroorganisme di tangan.

Tabel 3. Hasil Analisis Friedman data jumlah koloni mikroorganisme sebelum, sesudah tindakan handrub 1 dan handrub 5

\begin{tabular}{|l|l|c|}
\hline \multicolumn{1}{|c|}{ Perlakuan } & $\begin{array}{l}\text { Rerata } \\
\text { Jumlah } \\
\text { Koloni } \pm \text { S.d }\end{array}$ & \multirow{2}{*}{0.000} \\
\cline { 1 - 2 } Sebelum handrub & $38.05 \pm 34.2$ & \\
\cline { 1 - 2 } Sesudah handrub 1 & $6.20 \pm 16.6$ & \\
\cline { 1 - 2 } Sesudah handrub 5 & $3.15 \pm 12.41$ & \\
\hline
\end{tabular}

Sumber : Data Primer 2013

Uji Wilcoxon dilakukan dalam melakukan analisis post hoc untuk uji Friedman. Dari hasil uji tersebut, didapatkan perbedaan yang bermakna antara jumlah koloni mikroorganisme sebelum dan sesudah handrub pertama, jumlah koloni mikroorganisme sebelum dan sesudah handrub kelima, dan jumlah koloni mikroorganisme sesudah handrub pertama dan sesudah handrub kelima $(\mathrm{P}=0,000$ untuk ketiga perbandingan) (Tabel 4).

Tabel 4. Hasil Analisis Wilcoxon jumlah koloni mikroorganisme sebelum, sesudah tindakan handrub pertama dan handrub kelima

\begin{tabular}{|l|c|c|c|c|}
\hline Perlakuan & $\begin{array}{c}\text { Sampel dengan jumlah } \\
\text { koloni kelompok } \\
\text { pertama lebih tinggi } \\
\text { dari kelompok kedua }\end{array}$ & $\begin{array}{c}\text { Sampel dengan jumlah } \\
\text { koloni kelompok } \\
\text { pertama lebih rendah } \\
\text { dari kelompok kedua }\end{array}$ & $\begin{array}{c}\text { Sampel dengan jumlah } \\
\text { koloni kelompok kedua } \\
\text { sama dengan } \\
\text { kelompok pertama }\end{array}$ & P Value \\
\hline $\begin{array}{l}\text { Sebelum dan Sesudah } \\
\text { Handrub 1 }\end{array}$ & 77 & 3 & 8 & 0.000 \\
\hline $\begin{array}{l}\text { Sebelum dan Sesudah } \\
\text { Handrub 5 }\end{array}$ & 79 & 3 & 6 & 0.000 \\
\hline $\begin{array}{l}\text { Sesudah Handrub 1 dan } \\
\text { Sesudah Handrub 5 }\end{array}$ & 21 & 2 & 65 & 0.000 \\
\hline
\end{tabular}

Sumber : Data Primer 2013

\section{PEMBAHASAN}

Tangan merupakan media perantara yang paling sering menularkan mikroorganisme patogen penyebab HAls. Salah satu pencegahan HAls adalah dengan menjaga kebersihan tangan.
Secara individu cuci tangan dapat meningkatkan hieginitas yang dapat berpengaruh terhadap kesehatan. Kurangnya kepatuhan petugas dalam pelaksanaan kebersihan tangan adalah masalah yang dihadapi oleh rumah sakit di seluruh dunia. Kurangnya fasilitas 
seperti wastafel dan akses terhadap air bersih, sabun serta tisu pada titik pelayanan kesehatan merupakan kendala yang mempengaruhi kepatuhan mencuci tangan. Salah satu solusi terhadap hal ini yaitu dengan adanya alcohol-based handrubs. Mencuci tangan dengan alcohol-based handrubs tidak membutuhkan air bersih, sabun serta tisu dan dapat digunakan langsung di tempat bekerja $^{1,5}$.

Dari 69 petugas kesehatan dari ruang rawat TB, ruang rawat HIV-AIDS, ICU, ruang rawat anak dan ruang rawat kebidanan di RSPI Prof. Dr. Sulianti Saroso, mikroorganisme yang ditemukan lima jenis mikro organisme yang tumbuh di tangan responden sebelum handrub pertama, yaitu jamur, Staphylococcus epidermidis, Acinetobacter anitratus, Enterobacter cloacae dan Citrobacter sp. Sedangkan setelah handrub pertama dan kelima hanya ada dua jenis mikroorganisme yaitu, jamur dan Staphylococcus epidermidis dengan penurunan jumlah yang ditemukan.

Kulit merupakan tempat flora normal, kulit normal biasanya ditempati bakteria sekitar $10^{2}-10^{6} \mathrm{CFU} / \mathrm{cm}^{2}$. Flora normal yang menempati kulit terdiri dari dua jenis yaitu flora normal atau mikroorganisme sementara (transient microorganism) dan mikroorganisme tetap (resident microorganism) ${ }^{8}$.

The Association for Professionals in Infection Control (APIC) memberikan pedoman bahwa mikroorganisme transien adalah mikroorganisme yang diisolasi dari kulit, tetapi tidak selalu ada atau menetap di kulit. Mikroorganisme transien, yang terdiri atas bakteri, jamur, ragi, virus dan parasit, dapat berasal dari berbagai sumber yang pada akhirnya dapat terjadi kontak dengan kulit. Biasanya mikroorganisme ini dapat ditemukan di telapak tangan, ujung jari dan di bawah kuku. Mikroorganisme pathogen yang mungkin dijumpai di kulit sebagai mikroorganisme transien adalah Escherichia coli, Salmonella sp, Shigella sp, Clostridium perfringens, Giardia lamblia, virus Norwalk dan virus hepatitis $A^{9}$.

Flora tetap yang paling sering dijumpai adalah Staphylococcus epidermidis dan
Coagulase negative Staphylococcus lainnya, Corynebaterium dengan densitas populasi antara $10^{2}-10^{3} \mathrm{CFU} / \mathrm{cm}^{2}$. Flora tetap tidak bersifat patogen, kecuali Staphylococcus aureus. Bakteri ini dapat menyebabkan penyakit jika telah mencapai jumlah 1.000 .000 atau $10^{6}$ per gram, suatu jumlah yang cukup untuk memproduksi toksin. Flora anaerobik seperti Propionibacterium acne, tinggal di lapisan kulit lebih dalam, dalam folikel rambut, kelenjar keringat dan kelenjar Sebasea. ${ }^{8,10,11,12,13}$

Hasil analisis bivariat yang dilakuan mendapatkan adanya perbedaan jumlah koloni dari ketiga perlakukan (sebelum, sesudah tindakan handrub 1 dan handrub 5. Efektifitas dari tiga perlakuan dilihat dari rata-rata jumlah koloni yang tumbuh paling sedikit yaitu sesudah tindakan handrub 5 .

Ada kecenderungan penurunan jumlah koloni baik mikroorganisme transient maupun resdident, mulai dari sebelum handrub, sesudah handrub 1 dan sesudah handrub ke 5 (Tabel.3). Hasil penelitian ini juga memperlihatkan bahwa tindakan handrub merupakan perlakuan yang efektif dalam menekan dan meminimalisir jumlah koloni mikroorganisme ditangan hal ini ditunjukan dengan adanya perbedaan jumlah koloni mikroorganisme sebelum dan sesudah handrub 1 dan ke 5. (Tabel 4). Girou et al., membuktikan bahwa cuci tangan dapat menurunkan jumlah mikroorganisme di tangan hingga $58 \%{ }^{5}$.

\section{KESIMPULAN}

Tindakan handrub merupakan perlakukan yang efektif dalam menekan jumlah koloni mikroorganisme di tangan dan salah satu intervensi kesehatan yang murah dalam mengurangi risiko penularan penyakit. Penelitian lebih lanjut yang dikaitkan dengan pola kepekaan terhadap antibiotik mikroorganisme tersebut dan memperluas jangkaun tidak hanya pada kelompok resiko tinggi dapat dilakukan untuk memberikan gambaran lebih jelas tentang pola mikroorganisme yang ada dalam lingkungan rumah sakit, khususnya yang terdapat pada tangan petugas kesehatan sehingga dapat dilakukan intervensi yang lebih terarah dalam 
program pencegahan infeksi di rumah sakit.

\section{DAFTAR PUSTAKA}

1. WHO.Guidelines on Hand Hygiene in Health Care. 2009

2. Casewell M, Phillips I. Hands as route of transmission for Klebsiella species. B MJI, 1977, 2:1315-1317.

3. Ehrenkranz NJ, Alfonso BC. Failure of bland soap handwash to prevent hand transfer of patient acteria to urethral catheters. Infect Control Hospital Epidemiology 1991;12:65462.

4. Pittet D, Hugonnet S, Harbarth S, Mourouga P, Sauvan V, Touveneau S. Effectiveness of a hospital-wide programme to improve compliance with hand hygiene. Lancet. 2000;356:1307-12.

5. Girou, E., Loyeau, S., Legrand, P., Oppein, F., Buisson,CB. Efficacy of Handrubbing with an Alcohol Based Solution versus Standard Handwashing with Antiseptic Soap:randomized clinical trial. BMJ ; 2002 ;325: 362-5.

6. Boyce JM. It is time for action: improving hand hygiene in hospitals. Ann Intern Med 1999;130:153-5

7. Larson EL, Norton Hughes CA, Pyrak JD, Sparks SM, Cagatay EU,Bartkus JM. Changes in bacterial flora associated with skin damage on hands of health care personnel. Am J Infect Control1998;26:51321

8. Trampuz, Andrej and Widmer, A.F. Hand Hygiene: A Frequently Missed Live saving Opportunity During Patient Care, Mayo Clinic Proceedings, 2004 ; 79:109-116

9. Synder, Peter, O. Safe Hands Wash Program for Retail Food Operations, Hospitaly Institute of Technology and Management. St. Paul, MN;1988

10. Jawetz, Melnick, and Adelberg's. Mikrobiologi Kedokteran, Alih bahasa oleh Mudihardi, E., Kuntaman, Wasito, E.B., Mertaniasih, N.M., Harsono, S., dan Alimsardjono, L., Penerbit Salemba Medika, Jakarta;2005.
11. Widmer, AF. Replace Hand Washing with Use ofa Waterless Alcohol HandRub. Clinical Infectious Disease, 2000; 31:136-143.

12. Snyder, Peter. Why Gloves are not The Solution to The Fingertip Washing Problem, Hospitaly Instituteof Technology and Management. St. Paul, MN;2001.

13. Strohl, W.A., Rouse,H, Fisher,B.D, Lippincott's Illustrated Reviews: Microbiology, Lippincott Williams \& Wilkins, Pennsylvania; 2001 